\title{
Granting NaCl Compress To Extravasaion Prevention In Chemotherapy Patients At Ulin Hospital Banjarmasin
}

\author{
Istiqamah $^{* 1}$ \\ ${ }^{1}$ Sari Mulia School of Health Science, Pramuka No.2 Rt.07, Banjarmasin \\ Istiqamah@stikessarimulia.ac.id \\ Dini Rahmayani ${ }^{1}$ \\ ${ }^{1}$ Sari Mulia School of Health Science, Pramuka No.2 Rt.07, Banjarmasin \\ dini_rajmayani@stikessarimulia.ac.id \\ Subhannur Rahman ${ }^{1}$ \\ ${ }^{1}$ Sari Mulia School of Health Science, Pramuka No.2 Rt.07, Banjarmasin \\ subhan_nurrahman@stikessarimulia.ac.id \\ Rina Al Kahfi ${ }^{1}$ Ramadhan \\ Rina_alkahfi@stikessarimulia.ac.id \\ Ramadhan $^{1}$ \\ ${ }^{1}$ Sari Mulia School of Health Science, Pramuka No.2 Rt.07, Banjarmasin \\ ramdhan@gmail.com
}

\begin{abstract}
Objective: Extravasation is an effect of a highly unexpected chemotherapy drug administration, because it will cost patients a long time of care, cost, pain and also body image disturbance. The signs of extravasation should also be very recognizable. Extravasation can also cause permanent skin damage.

The purpose of this study is to determine whether there is a role of $\mathrm{NaCl}$ Compress Provision Against Extravasation Prevention In Chemotherapy Patients In Edelweis Room Ulin Hospital Banjarmasin.

Method: This research is Descriptive. The sample consisted of 46 respondents in the patients using Purposive sampling technique in accordance with inclusion and excretion kretiria. Data were collected using an observation sheet. The data are then analyzed using the results of the percentage observation sheet.

Result: The results showed the giving of $\mathrm{NaCl}$ compress to extravasation prevention on 46 respondents was very good. Judging from the percentage that $100 \%$ of patients who performed compress $\mathrm{NaCl}$ not seen signs of extravasation.

$\mathrm{NaCl}$ compresses are proven to prevent extravasation. This is evident from the absence of signs of extravasation in patients undergoing chemotherapy, meaning that the administration of $\mathrm{NaCl}$ compresses is very well done in patients undergoing Chemotherapy in Edelweiss Room of Ulin Banjarmasin Hospital.

Conclusion: The giving of $\mathrm{NaCl}$ compress is very good in the prevention of immediate extravasation at Ulin Hospital Banjarmasin.

Keywords: Nacl Compress, Extravasation Prevention, Chemotherapy, patient Chemotherapy
\end{abstract}




\section{INTRODUCTION}

Intravenous therapy cannot be separated from complications. Complications that can be obtained from intravenous therapy are systemic complications and local complications. Systemic complications are less common but are often more serious than local complications such as circulatory overload, air embolism, and infection. Local complications of intravenous therapy include infiltration, phlebitis, thrombophlebitis, hematoma, and extravasation [1].

Extravasation is a drug or fluid leak to the subcutaneous tissue of the vein or vascular tissue and damages tissue and skin necrosis. Extravasation destroys irreversible progressive tissue within hours to days. Extravasation events through an intravenous line averaged $0.1 \%$ to $6 \%$ via peripheral venous pathways. The incidence rate through the central venous catheter is $0.3 \%$ to $4.7 \%$ [2]. Extravasation events in adults are estimated between $0.1 \%$ and $6 \%$ [3]. Extravasation events were greater in women $(56 \%)$ than men $(42 \%)$, most found in the 50-64 age group. Extravasation incidence of chemotherapy by $7 \%$ [4]. According to research extravasation events in the ward of chemotherapy at the Regional General Hospital. Sardjito Yogyakarta with $12.7 \%$. Extravasation is one of the frightening complications that occur during chemotherapy drug administrator [3].

Risk factors that can lead to the extravasation of chemotherapy drugs with peripheral intravenous administration are edema, vascular location, chemotherapy drug type, radiation scar, venous weakness, reduced vascular integrity resulting in reduced elasticity, edema, trauma, canning, can nature, drug concentrations cytostatic, number of infiltrated drugs and long tissues exposed to drug infiltration [5]. This can harm patients because it can cause burns, pain, infection risk, dysfunction and can cause permanent damage [6].

Extravasation adds to the patient's pain, medical expenses, and can extend the patient's hospitalization time. The cost of treatment with chemotherapy is very expensive. Therefore, the provision of cytostatic drugs should pay attention to several things such as chemotherapeutic drugs, knowledge of nurses in administering chemotherapy and most importantly the selection of venous access sites and patency of venous [7].

$0.9 \% \mathrm{NaCl}$ is an isotonic liquid that is physiological, non-toxic and nonhypersensitivity so it is safe to use for the body under any circumstances, no irritant protects tissue granulation from dry conditions, keeps moisture around the wound and helps the wound go through the healing process. giving a $0.9 \% \mathrm{NaCl}$ compress on the wound can decrease the symptoms of edema because normal saline fluids may draw fluid from the wound through the osmosis process. In addition, $0.9 \% \mathrm{NaCl}$ has an anti-inflammatory response that can reduce the symptoms of pain and erythema that arise in the wound, and 
increase blood flow to the wound area, thus accelerating the wound healing process.

Based on the results of preliminary studies conducted by researchers on November 26, 2016, until December 10, 2016, obtained data of patients who experienced extravasation in 2015 as many as 6 people and in 2016 as many as 2 people. The number of patients undergoing chemotherapy in Edelweiss hospitals Ulin Banjarmasin is 558 patients in January to December 2015. One of the preventions of extravasation has been done in Edelweiss Room Ulin Hospital Banjarmasin with compressing $\mathrm{NaCl}$ compressing technique done with gauze dipped with $\mathrm{NaCl}$ sufficiently then compress $\mathrm{NaCl}$ done in the area around the stabbing. The $\mathrm{NaCl}$ compress was started in 2012 based on a comparative study by a medical team at one of the Canadian hospitals. In getting the results after applied the compress $\mathrm{NaCl}$ in RSUD Ulin Banjarmasin, especially in the Edelweiss room in this study has never done previous research .. Extravasation incidents in the hospital are not expected to happen because the hospital should be able to provide safe and uncomplicated services.

Based on the above background, researchers are interested to conduct research on "The Role of Provision of $\mathrm{NaCl}$ Compress Against Extravasation Prevention In Chemotherapy Patients In Edelweiss Room of Ulin Hospital Banjarmasin".

\section{METHODS}

The method used in this research is descriptive design. The population in this study were patients diagnosed with cancer patients in January 2017 which amounted to 558 people and the samples taken amounted to cancer patients who underwent chemotherapy treatment by using the sample formula according to [8] obtained the results of 46 samples, so the number of samples examined by researchers amounted to 45 people with purposive sampling technique.

Variable in this research is the activity of giving the role of $\mathrm{NaCl}$ compress to the prevention of Extravasation.

Data analysis method in the research includes the following:

a. Univariate Analysis

Univariate analysis was conducted on each variable from the research result to know the distribution, frequency, and percentage of each variable studied.

\section{RESULTS}

1. Univariate Analysis

a. Percentage of signs and symptoms in patients undergoing extravasation at the time of administration of $\mathrm{NaCl}$ compresses in patients Chemotherapy In Edelweiss Room Ulin Hospital Banjarmasin

Table 1 Signs and symptoms in chemotherapy patients in Edelweiss room Ulin Hospital Banjarmasin 2017 
From table 1, it can be seen that from 46 respondents with the giving of compress $\mathrm{NaCl}$ with for 6 hours can be seen there is no sign and symptoms of extravasation in a patient who underwent chemotherapy.

Percentage of incidence Extravasation $(<24$ hours $)$ in patients undergoing Chemotherapy in Edelweiss room Ulin Hospital Banjarmasin

Table 2 Incidence of Extravasation ( $<24$ hours) in patients with Chemotherapy in Edelweiss room Ulin Hospital Banjarmasin 2017

\begin{tabular}{llll}
\hline No & Categories & $\begin{array}{l}\text { Number of } \\
\text { Patients }\end{array}$ & $\%$ \\
\hline 1 & Extravasation & 0 & 0 \\
2 & No Extravasation & 46 & $100 \%$ \\
\hline & Jumlah & 46 & $100 \%$ \\
\hline
\end{tabular}

Table 2 shows that from 46 respondents with $\mathrm{NaCl}$ compress there is no incidence of extravasation at the time of administration of chemotherapy drugs either vesicant or iritan.

\section{DISCUSSION}

\section{Analisa Univariate}

a. Signs and symptoms in patients undergoing extravasation at the time of administration of $\mathrm{NaCl}$ compress in chemotherapy patients.

Based on the results of research conducted in the Edelweiss Room of Ulin Banjarmasin General Hospital, the researchers looked at 46 respondents seen in table 1 no signs of

\begin{tabular}{llll}
\hline No & Categories & Results & Percentage \\
\hline 1 & Painful & 0 & $0 \%$ \\
2 & Redish & 0 & $0 \%$ \\
3 & Swolen & 0 & $0 \%$ \\
4 & Erythema & 0 & $0 \%$ \\
5 & Induration & 0 & $0 \%$ \\
6 & Drug leak & 0 & $0 \%$ \\
& & & \\
\hline
\end{tabular}

immediate extravasation $(<24$ hours $)$ such as pain, redness, swelling, erythema, induration and no visible leakage drug. According to [5] mentions signs and symptoms Extravasation is pain, redness, swelling, erythema, induration as early symptoms of extravasation. Other factors also influence that the respondents encountered by the researchers do not see immediate extravasation $(<24$ hours $)$ first the venous selection in the average person using the metacarpal, safalica and antebrachial veins in which the vein is the most commonly used vein in intravenous therapy [9], the result of venous location factor was not related to Extravasation event. This happens because the type of condition of the vein is not straight and has an excessive movement so that infiltration of chemotherapy drugs can occur to the tissues around the blood vessels. This study found no correlation between venous location risk factor and Extravasation event because the nurse who will perform previous chemotherapy has given an explanation about the venous location to be used, so that patient understood and cooperative, and the patient can minimize movement of hand that infuses chemotherapy. Both age factors are also distant to the immediate extravasation ( $<24$ hours), The average patient who underwent chemotherapy 
aged 21-45 years or adult where at that age the condition of the immune system is very good, the vein is still in an elastic state reinforced by research [10] which mentions the anatomy of blood vessel physiology in children, adults and the elderly will be different structure and content of blood products itself for example in people who are young and productive with active activities make the flexibility of blood vessel walls and vice versa with the elderly will have stiffness in blood vessels that may pose a risk to the stabbing of the blood vessel wall during infusion. Factor is not happened eksavasasi one of them is caused by adult age which have elastic vein, not fragile, not hard and big, but on result of research conducted by researchers at Ulin Banjarmasin Regional General Hospital got patient happened Extravasation as many as 7 people between the ages of 21-45 years the results on 7 people is clear that can occur due to venous conditions. The third Standard of Operational Procedure (SOP) of infusion installation seen by the researchers, the nurses performed the infusion by using the Oprasional Prosuder Standard to all patients undergoing chemotherapy reinforced) mentions as many as $90.4 \%$ of patients who do not develop inflammation of the veins because the nurse performs the installation according to the operational standard procedure the result of the nurses who perform the action according to standard operational procedure is very good in preventing the occurrence of venous rupture and inflammation of the veins due to infusion stabbing. Fourth is the provision of chemotherapy drugs namely vesikan and iritan drugs according to inclusion criteria by researchers which is one cause of the occurrence of Extravasation according to [5] Extravasation is the breakup of blood vessels resulting from vesicant chemotherapy drugs and Iran, The theory is denied in the results of research [9] which mentions Extravasation on the vein does not occur despite using vesicant chemotherapy drugs.

Percentage of incidence Extravasation $(<24$ hours) in patients undergoing Chemotherapy in Edelweiss room Ulin Hospital Banjarmasin.

Provision of $\mathrm{NaCl}$ compresses to prevention Extravasation in patients undergoing Chemotherapy In Edelweiss Room Ulin Hospital Banjarmasin. Based on table 2 can be seen that 46 respondents with $100 \%$ percentage do not happen Extravasation seen from signs and symptoms Extravasation.

Based on the results of the research conducted in the Edelweiss Room of Ulin Banjarmasin General Hospital, the researchers also found that 46 respondents found that 8 people who experienced Extravasation (> 24 hours) in mild degree found after 2 days after completion of chemotherapy, also stated that patients with venous inflammation were seen after 2 days after intravenous therapy based on 11 patients from 109 patients studied.

Based on the in-depth observation conducted by the researcher to 8 respondents who experienced Extravasation in mild degree (> 24 hours), the first respondent happened on 
the 2nd and 3rd chemotherapy frequency with severe pain and redness. The second respondent occurs at the second frequency of chemotherapy with the presence of a bluish part of the hand. The third respondent occurred at 1 and 3 chemotherapy frequencies with severe pain, redness, and itching. The fourth respondent occurred at the third frequency of chemotherapy with bluish vein complaints. The fifth respondent occurred on the frequency of chemotherapy to 1 with complaints of flowering, redness, and itching. The sixth respondents occurred at the third frequency of chemotherapy with burning complaints. The seventh respondent occurred at the frequency of chemotherapy 1 and 3 with severe pain. The eighth respondent occurred at the second frequency of chemotherapy with severe pain. So it can be concluded that Extravasation arises in the implementation of chemotherapy to 1,2 and 3. Complaints of patients during the occurrence of Extravasation is severe pain, burning, itching, bluish scars and a sense of being rooted. According [5] Extravasation can be characterized by pain, redness, swelling, erythema and induration and in the study also mentioned At the Symptom of Extravasation seen when the infusion is attached that leads to necrosis, the patient complains of burning and swelling pain, which in 7 days later the patient complained of pain, edema, erythema, and induration. Untreated, vesicles and bullae may develop, followed by a large ulcer or placard with a necrotic central part that occurs within 1-3 weeks.
Researchers looked at risk factors based on 8 respondents who had all patients had large vein, elastic respondent veins, no edema in the stabbing site, no trauma due to stabbing, type of cannula used infusion set and blood set using about size $20-22$, drug concentration as prescribed by physician, duration of drug administration according to amount and prescribed medication, Extravasation respondents have spoken to the nurse of the room when the next chemotherapy and also there is silent did not inform the incident.

According to the statement of the respondents encountered by the researchers, when given a compress $\mathrm{NaCl}$ by the room nurse said "it feels comfortable, cool, cool" at the time of giving $\mathrm{NaCl}$ compress when undergoing chemotherapy. $\mathrm{NaCl}$ compresses are given during chemotherapy treatment from start to finish. According to doctors visit Canadian Hospital, $\mathrm{NaCl}$ compresses are very good in prevention of Extravasation, even nurses also say $\mathrm{NaCl}$ compress is very good and proven to decrease the incidence of Extravasation since compress $\mathrm{NaCl}$ done since the year 2012 [11].

\section{CONCLUSION}

Function of cold and warm compresses is included in one of prevention and treatment of Extravasation events. The role of giving $\mathrm{NaCl}$ compresses has the function of regulating thermoregulation in certain parts and safe to use in all patients of $\mathrm{NaCl}$ role other than as one in prevention of Extravasation study 
mention $\mathrm{NaCl}$ compress known have antiinflammatory response so it can decrease symptoms of pain and erythema which arise in the wound, as well as increase blood flow to the wound area, thus speeding up the wound healing process. In a study conducted on 46 respondents, all nothing happened extravasate based on signs and symptoms that appear. This is also reinforced by the research journal mentions the compress is also very good in reducing the degree of inflammation in the veins due to the installation of infusion.

\section{REFERENCES}

[1]. Cicilia, 2015. Faktor risiko dan kejadian Extravasation obat kemoterapi Tangerang: Universitas Pelita Harapan.

[2]. Chusni Mubarakh. 2013. Faktor risiko yang mempengaruhi kejadian Extravasation kemoterapi intravena perifer di rsup dr. sardjito Yogyakarta tahun 2011-2013 [tesis]. Yogyakarta : Universitas Gajah Mada.

[3]. Evangeline $\mathrm{H}$,dkk. 2015. Perbedaan kompres nacl 0,9\% dengan kompres alkohol $70 \%$ terhadap penurunan intensitas nyeri pada pasien flebitis. Cimahi : Sekolah Tinggi Ilmu Kesehatan Jendaral A. Yani.

[4]. DHS (2001a), Family Support Services: Enhanced Support for Families, Community Care Division, Victorian Government Department of Human Services, Melbourne

[5]. Horwath, J. \& Morrison, T. (2000), "Identifying and implementing pathways for organisational change: using the Framework for the Assessment of Children in Need and Their Families as a case example", Child and Family Social Work, vol. 5, pp. 245-254
[6]. Prilleltensky, I. \& Nelson, G. (2000), "Promoting child and family wellness: priorities for psychological and social interventions", Journal of Community and Applied Social Psychology, vol. 10, pp. 85-105

[7]. AIHW (2001), Child Protection Australia 1999-00, Catalogue No. CWS 13, Child Welfare Series no. 27, Australian Institute of Health and Welfare, Canberra

[8]. Woscan. 2009. Chemotherapy extravasation guideline. United kingdom : Woscan Cancer Nursing and Pharmacy Group

[9]. Nani Sutarni . 2007. Penatalaksanaan Extravasation. Jakarta : Rumah Sakit Kanker Dharmais.

[10]. Nurjanah, N. 2011. Studi Komparasi Efektivitas Kompres Normal Salin dan Air Hangat Terhadap Derajat Flebitis Pada Anak Yang Dilakukan Pemasangan Infus Di RSUP Dr. Hasan Sadikin Bandung. Tersedia pada : http://www.stikesayani.ac.id 
